\title{
Moscow Conspiracy of the Decembrists
}

\author{
M.S. Belousov
}

For citation: Belousov M.S. Moscow Conspiracy of the Decembrists. Vestnik of Saint Petersburg University. History, 2018, vol. 63, issue 1, pp. 29-40. https://doi.org/10.21638/11701/spbu02.2018.102

The article provides an insight into the important and crucial event in the history of the Decembrist Movement - the Moscow Conspiracy. This episode is related to one of the first planned attempts of the Decembrists on the life of an emperor. The subject has been widely covered by historiography; nevertheless, the question about the real motives for the regicide plan remains open. Research analysis reveals that even at the stage of investigation the government attempted at concealing the peasant causes of the Moscow Conspiracy. This effort, which can be traced in the report of the Committee of Inquiry, predetermined the perception of this issue by the pre-revolutionary historiography. The attempts to revise this tendency were made. For example, N. F. Lavrov tried to reconstruct the text of S. P. Trubetskoi's letter and demonstrated that the conspiracy was caused by the peasant issues. However, the concept of the Russian history, developed under Stalin, changed the direction of the studies. Thus, M. V. Nechkina explicitly stated that the main objectives of the movement were the deposition of the autocracy and the abolition of serfdom. The idea of interpreting the Moscow Conspiracy as an attempted resistance of the nobility to the authorities' plans to liberate the peasants would have become.This view prevailed both in the Soviet and foreign historiography for a long time. However, in the period of Perestroika S. V. Mironenko in his monograph comes up with the opposite view on this issue, arguing that the idea of regicide was related to Alexander I's alleged plans of retiring to Warsaw and sending the Manifest on the Liberation of the Serfs from there. This opinion was supported by many scholars. Furthermore, two previously unknown primary sources, discovered by P.V.Il'in and T.V.Andreeva, indicate that the causes of the Moscow Conspiracy were rooted in the fact that in 1817 the Decembrists strongly objected to the idea of the immediate abolition of serfdom carried out exclusively by the decision of the supreme authorities.

Keywords: the Decembrists, the Decembrist Movement, the Moscow Conspiracy, S.P.Trubetskoi, historiography.

\section{Московский заговор декабристов}

\author{
М. С. Белоусов
}

Для цитирования: Belousov M. S. Moscow Conspiracy of the Decembrists // Вестник Санкт-Петербургского университета. История. 2018. Т. 63. Вып. 1. С. 29-40. https://doi.org/10.21638/11701/ spbu02.2018.102

Belousov Mikhail S. - PhD, Associate Professor, St. Petersburg State University, 7-9, Universitetskaya nab., St. Petersburg, 199034, Russian Federation; m.belousov@spbu.ru

Белоусов Михаил Сергеевич - канд. ист. наук, доц., Санкт-Петербургский государственный университет, Российская Федерация, 199034, Санкт-Петербург, Университетская наб., 7-9; m.belousov@spbu.ru

This research was supported by the grant of the President of the Russian Federation for the young PhDs no. MK-5578.2018.6 "The movement of the Decembrists: from historiography to historical memory".

(C) Санкт-Петербургский государственный университет, 2018 
Статья посвящена важному и переломному событию в истории движения декабристов - Московскому заговору. Это событие связано с одной из первых попыток покушения на императора. Данный сюжет широко изучен в историографии, но до сих пор остается открытым вопрос об истинных причинах возникновения плана цареубийства. Проведенный анализ показывает, что уже в период следствия правительство было заинтересовано в сокрытии крестьянских причин Московского заговора. Обозначенное стремление отразилось в Донесении следственной комиссии и предопределило восприятие данной проблематики в дореволюционной историографии. Предпринимались попытки пересмотреть это положение. Н. Ф. Лавров попытался реконструировать текст письма С. П. Трубецкого и показал, что причина заговора связана с крестьянским вопросом. Тем не менее формирование сталинской историографии русской истории изменило вектор исследований данного сюжета. М. В. Нечкина однозначно утверждала, что главные цели движения - свержение самодержавия и отмена крепостного права. Увидеть в событиях Московского заговора попытку сопротивления дворянства планам по освобождению крестьян стало бы политическим парадоксом. Такая точка зрения господствовала как в советской, так и в зарубежной историографии длительный период. Несмотря на это, уже в годы перестройки появилась монография С. В. Мироненко, где анализируемый сюжет получил прямо противоположную интерпретацию: план совершения цареубийства был связан с известиями о стремлении Александра I уехать в Варшаву и прислать оттуда манифест об отмене крепостного права. Данную точку зрения поддержали многие исследователи, а усилиями П.В.Ильина и Т.В. Андреевой было обнаружено два новых, ранее неизвестных источника, анализ которых однозначно указывает на причины возникновения Московского заговора: в 1817 г. декабристы были категорически против одномоментной ликвидации существующих поземельных отношений решением исключительно верховной власти.

Ключевые слова: декабристы, движение декабристов, Московский заговор, С.П.Трубецкой, историография.

In 1817, an important and crucial event, which subsequently was referred to as the "Moscow Conspiracy", occurred in the history of the Decembrist Movement. As its dynamics unfolds, in August 1817, Alexander I went to Moscow to take part in the ceremony of laying the foundation stone of the Cathedral of Christ the Savior on Vorob'ovy Gory in honor of the victory over Napoleon's army in the Patriotic War of 1812. The emperor was accompanied by the officers of the guard, with most of them being members of the Union of Salvation. As M. V. Nechkina aptly observed, this journey truly was "a journey of committed and faithful sons of their fatherland from St. Petersburg to Moscow"1.

In September 1817, S. P. Trubetskoi, who remained in St. Petersburg, was informed by prince Lopukhin about Alexander I's alleged plans for immediate reforms. He decided to share these rumors with those members of the Union of Salvation, who resided in Moscow at the time. It was agreed to discuss the news at the apartment of A. N. Murav'ev. N.M.Murav'ev, brothers Murav'ev-Apostols, I. D. Iakushkin, M. A. Fonvizin, F. P.Shakhovskoi and M.S. Lunin took part in the meeting ${ }^{2}$. In the course of heated discussion the letter was reread more than once. Eventually, the decision to attempt on the emperor's life was made. I. D. Iakushkin volunteered to do this, not willing to "cede this honorable duty" to anyone else ${ }^{3}$. Next day the same people met again at M. A. Fonvizin's place. This

${ }^{1}$ Nechkina M. V. Dvizhenie dekabristov. Moscow, 1955. Vol. 1. P. 175.

2 Porokh I. V. Deiatel'nost' dekabristov v Moskve (1816 1825 gg.) // Dekabristy v Moskve. Trudy muzeia istorii i rekonstruktsii Moskvy. Moscow, 1963. Vol. 8. P. 20.

3 Zapiski, stat'i, pis'ma dekabrista I. D. Iakushkina. St. Petersburg, 2007. P. 17. 
time most of the attendants spoke against the regicide plan. Thus, the conspiracy did not exceed the bounds of one meeting, accompanied by heated debate.

This event has been thoroughly examined in many studies, but the question of the motive for the regicide plan still remains open. The Moscow Conspiracy is associated with one of the first planned attempts on the life of an emperor. Hence, it was a serious political offence. According to the Council Code, those who committed it were to be sentenced to quartering. That is why the situation drew the attention of the Committee of Inquiry. All the individuals, mentioned in the context of these events, were questioned and their accounts recorded. The results of the investigation were expounded in the Committee's report ${ }^{4}$.

This document, which expressed the government's view on the Decembrist Movement, offered the following outline of the events of 1817. According to it, S.P.Trubetskoi in his letter to A.N.Murav'ev revealed that "His Majesty the tsar wanted to return all the occupied lands to Poland and, foreseeing the negative reaction and even resistance on the part of the Russians, planned to retire to Poland with his retinue, leaving the country in the state of

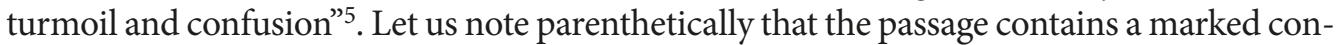
tradiction: the report states that S.P. Trubetskoi addressed this letter to A.N.Murav'ev, while S.P.Trubetskoi himself asserted that he had delivered the news to S. I. Murav'ev-Apostol' ${ }^{6}$. N. M. Murav'ev, in turn, claimed that S. P. Trubetskoi's letter had been sent to I. D. Iakushkin ${ }^{7}$. Anyway, the information aroused the indignation of the members of the secret society and they ventured to plot the regicide. The report proceeds with the assumption, that at that period I.D. Iakushkin suffered from unrequited love and volunteered to sacrifice his life and execute the regicide. The report implies that the patriotic feelings of the Decembrists were offended: the emperor planned the annexation of western provinces to Poland and the conspirators made up their minds to attempt on his life.

The author of the report refers to this episode using the adjective "absurd": absurd rumor was set afloat, I. D. Iakushkin's conduct was absurd. Despite the significance of the event, the report did not pay much attention to it. These circumstances had an influence on the pre-revolutionary historiography. Most of the scholars simply missed this episode. Thus, in the works of A.N.Pypin and V.I.Semevskii, which represent the fundamental studies of that period, the story of the Union of Salvation is immediately followed by the account of the Union of Prosperity formation process.. However, the authors of biographical studies took interest in the details of the Moscow Conspiracy. Of these the work by N. F. Lavrov - "The Dictator of December $14^{\text {th" }}$ should be singled out.

The biographer of S. P. Trubetskoi mostly focused on the reconstruction of the letter, which had been lost. N. F. Lavrov defined and analyzed a wide range of sources, which could throw light on its content. Among these there were the "Historical Agenda of the Society" by N.M. Murav'ev, the accounts and "Notes" by S. P. Trubetskoi and the memoirs by I. D. Iakushkin. As a result, N.F. Lavrov made the conclusion that the letter contained the following information: "1) the tsar was fascinated by Poland, ...2) he hated Russia, 3) he made plans for the annexation of the former Polish provinces to Poland...4) he was

${ }^{4}$ Vsepoddanneishii doklad vysochaishe uchrezhdennoi Sledstvennoi komissii ot 30 maia $1826 \mathrm{~g}$. // Vosstanie dekabristov. Materialy po istorii vosstaniia dekabristov. Moscow, 1980. Vol. 17. P.24-62.

5 Ibid. P. 27.

${ }^{6}$ Delo kniazia S. P. Trubetskogo // Vosstanie dekabristov: Materialy po istorii vosstaniia dekabristov. Moscow; Leningrad, 1925. Vol. 1. P. 49.

7 Ibid. P. 306. 
considering the removal of the capital to Poland, 5) All these actions aimed at securing the support of the Poles in the case of disturbances in Russia in the wake of the organization of military colonies and, finally, 6) Alexander I intended to liberate the peasants and (in the case of dissent on the part of the nobility) to retire to Warsaw and send the Manifest on the Liberation of the Serfs from there"8.

Having highlighted the crucial passages of the letter, N. F. Lavrov, however, confined himself to making brief mention of them, and did not come up with any comprehensive conclusions. It is noteworthy that the reconstruction of the letter, carried out by the author, proved to be rather embarrassing for Soviet researchers. The sources clearly indicate that the animosity was caused by Alexander I's intention to abolish serfdom. The acceptance of the fact that one of the reasons for Decembrists' regicide plot was rooted in the authorities' plans to liberate the serfs, would have ruined a well-established myth about the pioneers of revolutionary movement - the forerunners of Bolsheviks.

Another biographer, N.M.Druzhinin, in his work "Decembrist Nikita Murav'ev", also focused on that period, dwells on the Moscow Conspiracy. The historian is certain about the roots of the conspiracy: according to N.M. Druzhinin, S. P. Trubetskoi reported about the plans of the annexation of the Lithuanian provinces to Poland ${ }^{9}$. Nevertheless, the scholar believed these events to have been one of the first attempts of the Decembrist revolution, emphasizing that their main objective was a "radical change of the form of government and an overall social reform" rather than a mere regicide ${ }^{10}$. However, having stated this, the author immediately added that the revolutionary movement assumed a habitual form of a coup initiated by the nobility.

M. V. Nechkina in her work continued on the same lines, arguing that S.P. Trubetskoi's letter was read at the time of a heated debate, accompanied by the feeling that "Russia was on the edge of the downfall"11. According to the author, members of the Union of Salvation were ready for the revolt and the "prospective withdrawal of vast indigenous Russian territories" gave rise to "ultimate outrage and the call for immediate action"12. M. V.Nechkina treats the peasant issue as a question of minor importance claiming that "prison accounts of the Decembrists often touched upon the prospective liberation of peasants on the above-mentioned territories and the resulting uprising of the Russian peasants, who were allegedly destined to remain the serfs"13. The author's outline of the events is quite coherent: Alexander I planned the annexation of western provinces to Poland and the abolition of serfdom there, thus, triggering the peasant riot in Russia. Hence - the Decembrists protested against the humiliation of the nation, not against the abolition of serfdom.

Therefore, it can be concluded that due to the efforts of the Soviet historians of the 1930s-1950s the Moscow Conspiracy was recognized as a significant episode in the history of the Decembrist movement. However, despite the important observations of N. F. Lavrov, the opinion, originally expressed by the report of the Committee of Inquiry (that the regicide plot was rooted in the offended patriotic feelings of the Decembrists, concerned about the annexation of Russian provinces to Poland) became a prevailing one. Previous-

${ }^{8}$ Lavrov N. F. Diktator 14 dekabria // Bunt dekabristov. Leningrad, 1926. P. 153.

9 Druzhinin N.M. Dekabrist Nikita Murav'ev // N.M. Druzhinin. Revoliutsionnoe dvizhenie v Rossii v XIX veke. Izbrannye trudy. Moscow, 1985. P. 73.

10 Ibid. P.74.

11 Nechkina M. V. Dvizhenie dekabristov. Vol. 1. P.176.

12 Ibid. P. 177.

13 Ibid. P. 176. 
ly, although with regard to another subject, we already mentioned the similarity of the official historical concepts of Nicholas I's and Stalin's periods, developed by D. N. Bludov and M. V. Nechkina respectively ${ }^{14}$. It is worthy of note that the position of M. V. Nechkina was virtually never challenged. Some scholars obviously run into extremes: for example, I. A. Mironova, the biographer of I. D. Iakushkin, demonstrates the revolutionary spirit of the early Decembrist groups and states that the issue of regicide originated quite naturally in the course of their activities. In this context the Moscow Conspiracy is often referred to, but the author does not consider it necessary to examine its causes. The text implies that the regicide plot was a natural stage in the development of the movement ${ }^{15}$.

It should be taken into consideration that the tendency of interpreting the Moscow Conspiracy as an insignificant episode is typical of the pre-revolutionary historiography in general and of the émigrés-historians, in particular. For example, G. V. Vernadskii, famous for his meticulousness, omits this issue in his review article ${ }^{16}$. Another émigré-historian A. G. Mazour describes the situation as following: in 1817 the Union of Salvation saw the intensive rivalry between the parties, which advocated radical and moderate views. This rivalry took place in the period when "military colonies were being mercilessly enforced by Arakcheev, the Polish constitution had just been granted. At that time a letter came from Trubetskoi reporting persistent rumors that Alexander I favored an autonomous Poland and was considering the removal of the capital to Warsaw and the annexation to Poland some of the bordering Russian provinces"17. This provoked an outbreak of indignation and inspired the Decembrists to plot the attempt on his life. Therefore, one of the celebrated monographs about the Decembrists written by an American historian offers the interpretation of the events which is very close to the one produced by the report of the Committee of Inquiry.

Apparently, the question of the causes of the Moscow Conspiracy had been cleared by 1950: both Soviet and foreign historiographies had given concordant answers to it. That is why it does not come as a surprise that this interpretation had been beyond any doubts for a long time. W. L. Blackwell in his article focused on the Decembrists' attitude to the Polish question emphasizes that "Alexander I's pro-Polish policy in the half decade following the Congress of Vienna provoked vigorous and hostile reaction in Russia, and it is to be expected that the young liberal nationalists of the early Decembrist groups also would develop animosities toward the Poles"18. Analyzing the events of the Moscow Conspiracy, the author is firmly convinced that it was the prospective annexation of the Russian provinces to Poland that provoked the animosity ${ }^{19}$.

It should be noted that W.L. Blackwell defined the pro-Polish policy of Alexander I as one of the central factors in the formation of the first secret societies. Another western scholar, F. A. Walker, is even more strongly-worded in his treatment of the Moscow Con-

${ }_{14}$ Belousov M. S. "Predatel'stvo" S. P. Trubetskogo: pro et contra // Vestnik of Saint-Peterburg University. History. 2014. Issue 4. P. 15-30.

${ }_{15}$ Mironova I. A. Dekabrist Ivan Dmitrievich Iakushkin. Moscow, 1987. P. 20-21.

16 Vernadskii G. Dva lika dekabristov // Svobodnaia mysl'. 1993. N 15. P. 81-92. - A detailed analysis of the views of the Russian-American scholar on the history of the movement of the Decembrists see: Dvornichenko A. Y., Belousov M. S. Dvizhenie dekabristov v tvorchestve Georgiia Vernadskogo // Vestnik of Saint-Peterburg University. History. 2017. Vol. 62. Issue 2. P. 358-374.

17 Mazour A. G. First Russian revolution 1825. The Decembrist movement. Its origins, development and significance. Stanford (California), 1937. P.71.

18 Blackwell W.L. Russian decembrist views of Poland // The Polish Review. 1958. Vol.3, no. 4, Autumn. P. 31-32.

19 Ibid. P. 34. 
spiracy: "Hostility to Poland had been an important factor in the origin of Russian secret societies" ${ }^{20}$. It should be observed that in the works of the above-mentioned historians the disapproval of the pro-Polish policy of Alexander I smoothly transformed into the hostility towards Poland itself. Nevertheless, it is very important that, as we have demonstrated, western scholars in their interpretation of this issue rely on the version represented in the report of the Committee of Inquiry and later on revived by the Soviet historiography.

The works by S. V. Mironenko, who continued the research of this issue, produced an impression of a bolt from the blue (at least on an attentive reader). The historian, who acknowledges the detailed systematic study of this topic, claims that the "subject of the secret society's heated debate in autumn 1817 was never clarified fully"21. S. V. Mironenko's monograph offers a completely new interpretation of the related sources. The author indicated that at the interrogation the Decembrists claimed that it was the alleged annexation of the western provinces to Poland that gave rise to the conspiracy. In the "Historical Agenda of the Society" by N.M. Murav'ev the Polish issue is indeed closely intertwined with the peasant one. The "Notes" by S. P. Trubetskoi provide the following outline of the events: Alexander I intends to liberate the peasants and in the case of the negative reaction of the nobility - to leave for Warsaw and to send the Manifest on the Liberation of the Serfs from there. These actions would inevitably have resulted in the public disturbances and revolt. Thus, according to the "Notes", the letter gave an account of the serfdom abolition plans and the possible ways of avoiding the resistance of the nobility.

S. V.Mironenko states that the "evidence of S.P. Trubetskoi (which features in the "Notes". - M. B.) should not be underestimated, as it was he who informed other Decembrists about the plans of Alexander I"22. Moreover, the "Historical Agenda of the Society" advocates the same idea as the one put forward by S. P. Trubetskoi but in the context of Alexander I's pro-Polish views. S. V. Mironenko also provides another "forcible confirmation" - the account of E. I. Iakushkin, recorded by N. K. Schilder in 1897. The son of I. D. Iakushkin, who dedicated his life to the study of the movement, narrated: "Iakushkin volunteered to murder the tsar in $1819^{23}$. It was rumored that the tsar would retire to Warsaw to issue the manifest about the "reforms". The Decembrists were convinced that "it would entail the massacre of all landlords" and decided to kill the tsar in order to prevent it"24.

S. V. Mironenko came up with the concept which runs counter to the entrenched stereotypes about the causes of the Moscow Conspiracy. However, later on, unfortunately, he renounced his point of view. Giving a talk at the jubilee conference in 2015, the historian referred the attempted regicide to the offended patriotic feelings of the Decembrists ${ }^{25}$. A year later another monograph of S. V. Mironenko was released. One of the chapters gave

20 Walker F. A. Poland in the Decembrists' strategy of revolution // The Polish Review. 1970. Vol.15, no. 2 (Spring). P. 44.

${ }_{21}$ Mironenko S. V. Samoderzhavie i reformy. Politicheskaia bor'ba v Rossii v nachale XIX veka. Moscow, 1989. P. 85.

22 Ibid. P. 87.

${ }^{23}$ Incorrectly named year S. V. Mironenko explains that E. I. Yakushkin talked about the Moscow conspiracy, already in old age (Ibid. P. 92).

${ }_{24}$ Otdel rukopisei Rossiiskoi natsional'noi biblioteki (OR PNB). F. 859. K. 38. N 15. L. 16.

${ }^{25}$ Andreeva T. V., Il in P. V., Belousov M. S., Ivanova T. A., Kuznetsova S. D., Parshina A. V., Smirnov A. O. Istoricheskaia pamiat' Rossii i dekabristy. 1825-2015 // Vestnik of Saint-Peterburg University. History. 2016. Issue 2. P. 169. 
a detailed account of the statements of the Decembrists and of the roots of the Moscow Conspiracy. However, the author doesn't provide his own clear view on its causes ${ }^{26}$.

The opinion expressed by S. V. Mironenko as early as in the 1980s enjoyed the support of the post-Soviet historiography, in particular, due to the discovery of the new sources. For example, P.V.Il'in found an entirely new version of S.P. Trubetsloi's notes and highlighted that the document gave a chance to identify the source of information about the reformatory plans of Alexander I. It was traditionally believed by the scholars that S. P. Trubetskoi had learned about the alleged plans of the tsar to move to Warsaw and issue the Manifest on the Liberation of the Serfs from there from his close friend P.P.Lopukhin. This grew out of the fact that in the early version of the notes the surname was mentioned without the initials. However, the version discovered by P.V.Il'in clearly indicates that it was P. P.Lopukhin's father, the chairman of the State Council and the Committee of Ministers P. V.Lopukhin, who confided in S. P. Trubetskoi. The historian considers "this to be a key factor for the assessment of the credibility and significance of the information" 27 obtained by S. P. Trubetskoi and passed in the letter to fellow Decembrists in Moscow.

D. S. Artamonov endeavored to conduct a comprehensive study of the origins, course and significance of the Moscow Conspiracy. His article claims that "S. V. Mironenko provided stringent arguments, that the conspiracy had been caused by the alleged peasant liberation plans, mentioned in the letter of Trubetskoi"28. The scholar noticed that the accounts of most of the Decembrists were at variance with this conclusion and presumed that the "Decembrists had forgotten about this news in the letter or had been reluctant to impart it to the investigators" 29 . As the "abolition of serfdom was reportedly one of the main objectives of the secret society it apparently could not have given rise to the regicide plot" ${ }^{\prime 3}$. Thus, there is no doubt that D. S. Artamonov supported the ideas of S. V. Mironenko.

E. N. Tumanik in her biographic study of the life of A. N. Murav'ev also touches upon this subject ${ }^{31}$. The scholar shares the observations of S. V. Mironenko, specifying and clarifying some of them. For example, she gives attention to the fact that the personal file of A. N. Murav'ev lacked any information about the peasant issue, in general, and the Moscow Conspiracy, in particular. She adheres to the opinion that it could be accounted for by A.N. Murav'ev's profound knowledge of the reformatory plans of Alexander I and the reluctance of the investigators to dwell on this issue. It is noteworthy that the analysis of this topic encouraged E. N. Tumanik to come up with the following conclusion: "it was a striking political paradox - the Union of Salvation members, whose activities were aimed at the abolition of serfdom, vigorously opposed this reform"32. M. M. Safonov's approach towards the study of the Moscow Conspiracy was different ${ }^{33}$; he focused on the procedure and manner of the interrogation of the Decembrists. The scholar claims that the investi-

${ }^{26}$ Mironenko S. V. Aleksandr I i dekabristy. Rossiia v pervoi chetverti XIX veka. Vybor puti. Moscow, 2016.

27 Il'in $P$. V. Novoe ob istorii dekabristskogo dvizheniia (po stranitsam neizvestnoi rukopisi zapisok S. P. Trubetskogo) // Otechestvennaia istoriia. 2003. N 6. P. 141.

28 Artamonov D.S. Iz istorii "Moskovskogo zagovora" 1817 goda // Osvoboditel'noe dvizhenie v Rossii. Saratov, 2006. Vol.21. P. 55.

${ }^{29}$ Ibid. P. 57.

30 Ibid.

31 Tumanik E. N. Aleksandr Nikolaevich Murav'ev. Nachalo politicheskoi biografii i osnovanie pervykh dekabristskikh organizatsii. Novosibirsk, 2006.

32 Ibid. P. 202.

33 Safonov M. M. "Moskovskii zagovor" 1817 g. i krest'ianskii vopros // Dekabristy v Ukraine. Kiev, 2012. Vol. 7. P. 203-212. 
gation started with the questioning of P. G. Kakhovskii. According to M. M. Safonov, the statements of P.G. Kakhovskii should be interpreted in the following way: "The secret society originated for the purpose of preventing the nobility from seeking the limitation of the supreme power at the price of the liberation of the serfs" ${ }^{\prime 2}$. After that the investigators conducted number of interrogations and, as M.M.Safonov argues, were faced with a complicated paradox: "the secret society, which they portrayed as a criminal organization, in fact, proved to be a champion of the nobility's interests" ${ }^{35}$. After the first interrogations the Committee of Inquiry changed the tactics and went on with the questioning, twisting the content of the statements to suit the purpose of avoiding the peasant issue. Thus, as M. M. Safonov claims, the investigation bodies were eager to soft-pedal the peasant problems and tried to produce an impression that the regicide plot had been) triggered by the Polish issue in the first place.

Summing up all the opinions existing in historiography, we should mention that with reference to the content of S. P. Trubetskoi's letter, which provoked the Moscow Conspiracy, two concepts can be distinguished in the scholarly literature. For convenience they can be titled "the patriotic" one and "the peasant" one. According to the first concept, the letter said that Alexander I was planning the annexation of the western provinces to Poland. It was a hard blow to the patriotic feelings of the Decembrists, which resulted in the regicide plot. The advocates of the "peasant" concept assert that S. P. Trubetskoi revealed the plans of the emperor to abolish serfdom and (in the case of hostile reaction of the nobility) to go to Warsaw and send the respective manifest from there. The prospective escape of the emperor and the subsequent manifest could have provoked the revolt of the peasants against the nobility, similar to the "Pugachov rebellion". Consequently, such a prospect urged the Decembrists to plan attempts on his life.

In the context of the research it is important to focus on the findings by P.V.Il'in about the source of information passed by S. P. Trubetskoi to his companions. In his statement of January 10th Trubetskoi insisted that "he really did hear the above-mentioned news from the former aide-de-camp to his Majesty the Emperor and the current Major-General Prince Lopukhin"36. In the "Notes" S. P. Trubetskoi emphasizes the fact that the Decembrists became aware of the "open-hearted conversation between the tsar and prince Lopukhin" 37 . "The scholarly comparison of these two sources gave rise to the well-established view that the emperor had confided in the aide-de-camp P.P.Lopukhin" 38 . Therefore, the history allegedly ran as follows: Alexander I told P. P. Lopukhin about his intentions, the latter passed the information to S. P. Trubetskoi and he, in turn, to the members of the Union of Salvation, who resided in Moscow.

After the interrogation of the conspirators, The Committee of Inquiry summoned P.P. Lopukhin for questioning. P. P.Lopukhin stated that "he had never discussed the rumors about the withdrawal of Polish provinces with his companions, but told Trubetskoi once about the surprising tendency to separate Lithuanian and Russian forces and to appoint only the natives of those provinces to serve there $\langle\ldots\rangle$. The idea of the annexation

34 Ibid. P. 203.

35 Ibid. P. 205.

36 Delo kniazia S. P. Trubetskogo // Vosstanie dekabristov. Materialy po istorii vosstaniia dekabristov. Moscow; Leningrad, 1925. Vol. 1. P. 49.

37 S. P. Trubetskoi. Materialy o zhizni i revoliutsionnoi deiatel'nosti. Irkutsk, 1983. Vol. 1. P.223.

38 Il'in P. V. Neizvestnye zapiski S. P. Trubetskogo // S. P. Trubetskoi. Zapiski. Pis'ma I. N. Tolstomu 1818-1823 gg. St. Petersburg, 2011. P. 40. 
of these provinces to Poland was suggested as one of the possible explanations" ${ }^{\prime 3}$. In the course of investigation P. P. Lopukhin did not mention his conversation with the emperor, but chose neutral wording, reducing the information given by him to S.P. Trubetskoi to the domain of guesses and speculation. P. P. Lopukhin provided a minute account, which rather sustained a "patriotic" concept of the conspiracy.

Another version of S.P. Trubetskoi's "Notes" (from the collection of I. A.Shliapkin) can explain the reticence of P. P. Lopukhin. This source features the episode in more detail. In particular, the sentence about an "open-hearted private conversation of the tsar with prince Lopukhin" is recorded as an "open-hearted private conversation with the chairman of the State Council prince Lopukhin" ${ }^{\prime 0}$. It indicates that the tsar confided not in P. P. Lopukhin, but in his father P. V. Lopukhin. This gives a new turn to the situation: Alexander I told about his intentions to P. V.Lopukhin, the latter reported the news to his son, who, in turn, shared it with S.P. Trubetskoi, and through him the information reached the ears of the Union of Salvation members in Moscow.

This reconstruction of the events explains the reticence of P.P.Lopukhin at the questioning. He did not want to give away his father as it could ruin his reputation. That is why he spoke vaguely about the obtained information and presented it as a personal impression. It is also worthy of note that this detail largely changed the status of the news. It turned out that Alexander I shared his serf liberation plans with the highest official, the chairman of the State Council and the Committee of Ministers and last, but not least, the head of the law-making Committee. The statement given to a person of such a high rank is much more authoritative than a casual remark addressed to an aide-de-camp.

Moreover, one more source which was recently discovered by the scholars - the letters of S.P. Trubetskoi to I. N. Tolstoi adds another element to the puzzle. In the context of the research issues under investigation the letter of November $12^{\text {th }} 1818$ should be singled out $^{41}$. In this letter S. P. Trubetskoi comments on Alexander I's speech at the Aachen Congress of the Holy Alliance on the abolition of the black slaves' trade and his promise to liberate the serfs in Russia. In the letter S. P. Trubetskoi presented his view on the prospective reforms and advised I. N. Tolstoi on how to react to the forthcoming events. According to T. V. Andreeva and P.V.Il'in "these recommendations show resemblance to the concerns expressed by other members of the Union of Prosperity with regard to similar rumors which had emerged somewhat earlier and had given rise to the Moscow Conspiracy" 42 .

Thus, T.V.Andreeva and P.V.Il'in believe that it is possible to draw an analogy between these two events and to apply the above-mentioned source to the reconstruction of S.P. Trubetskoi position regarding the situation in September 1817. This point of view can hardly be disputed. Within the examined period the peasant issue often gave rise to the heated public debate. S.P. McCaffray argued that the peasant problem was one of the burning issues discussed by the ruling circles at that time ${ }^{43}$. The rumors about the refor-

39 Delo P. P. Lopukhina // Vosstanie dekabristov. Materialy po istorii vosstaniia dekabristov. Moscow, 2001. Vol.20. P. 438.

40 Il'in P. V. Neizvestnye zapiski S. P. Trubetskogo. P. 56.

${ }^{41}$ Pis'ma S. P. Trubetskogo I. N. Tolstomu 1818-1823 gg. // S. P. Trubetskoi. Zapiski. Pis'ma I. N. Tolstomu 1818-1823 gg. St. Petersburg, 2011. P. 190-191.

42 Andreeva T. V., Il'in P. V. Pis'ma S. P. Trubetskogo I. N. Tolstomu // S. P. Trubetskoi. Zapiski. Pis'ma I. N. Tolstomu 1818-1823 gg. St. Petersburg, 2011. P. 177.

${ }^{43}$ McCaffray S. P. Confronting Serfdom in the Age of Revolution: Projects for Serf Reform in the Time of Alexander I // The Russian Review. 2005. Vol. 64, no. 1. P.1-21. 
matory plans of Alexander I and the liberation of the serfs merged together. It is no coincidence that S. P. Trubetskoi in his "Notes" examines the history of the Moscow Conspiracy in connection with the liberation of the serfs in the Baltic provinces, the speeches of Alexander I at the meeting of Little Russian nobles and the distribution of the manuscripts on peasant problems around Moscow.

Having acknowledged that the above-mentioned source is suitable for the reconstruction of S. P. Trubetskoi's view on the Moscow Conspiracy, we will focus on its content. The letter states that Alexander I "solemnly promised to liberate the white slaves of his country" ${ }^{\prime 4}$. Furthermore, just like in autumn 1817 the reform under discussion was unprepared and unexpected. S. P. Trubetskoi gives an account of the emperor's deeds: "He has left his mother and spouse abroad and come back alone to announce his decision. Nobody knows how he is going to do it"45. In this outline the opposition between the emperor and the nobility can be traced. Alexander I is portrayed as a conspirator who ensured the safety of his family and was planning the liberation of the serfs in secret. S. P. Trubetskoi is certain about the outcome of this act: "We will see what happens. One has to be ready just in case - if he really announces this, we will be facing a hopeless mess" ${ }^{46}$. S. P. Trubetskoi has no doubts about the consequences - if the tsar delivers his promise, it will result in turmoil.

The next passage is really interesting: "Foreign politicians definitely realize that this event will give rise to universal uprising" ${ }^{\prime 7}$. Thus, the idea that the liberation of the serfs would entail negative implications in the form of a civil riot, was, according to S.P. Trubetskoi, obvious not only to him, but to the Russian landlords and even "foreign politicians" as well. S.P. Trubetskoi was convinced that the reform would bring nothing but large-scale disturbances.

The letter highlights the inevitability of the riot. After mentioning some casual events, S. P. Trubetskoi reports: "This is crucial news I want to impart to you..." 48 . It is noteworthy that S. P. Trubetskoi delivers the news in a hurry: "I got to know it only yesterday" ${ }^{49}$. Retelling the rumors about the intentions of Alexander I, S. P. Trubetskoi promises his friend to keep him posted: "As soon as I know more, I will update you" ${ }^{0}$. In conclusion of his letter S. P. Trubetskoi advises I. N. Tolstoi to inform his brother Iakov about the situation: "I will not write to Iakov, you tell him about this"51.

Thus, there were rumors about the prospective plans of the emperor. S.P. Trubetskoi believed that the realization of those plans would inevitably result in a peasant revolt. The political convictions of S. P. Trubetskoi, who was a member of the secret society, manifest themselves in his plan of action - he suggests keeping up with the new information and advises his friend "to prepare" 52 . In particular, he recommends I.N. Tolstoi "to take precautions" 53 and be with his family when the time comes. Hence, S. P. Trubetskoi foreseeing

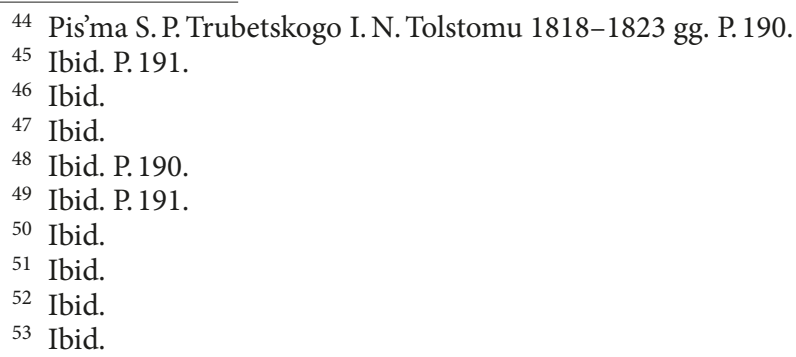


that the deeds of the emperor would trigger a national catastrophe - a large-scale peasant riot - did not seek ways of preventing it, but was preparing to undergo the forthcoming terrible ordeal concerned only about the safety of his family.

Reverting to the circumstances of the Moscow Conspiracy, it can be assumed that it was S. P. Trubetskoi's prospective line of action in view of the forthcoming events. This hypothesis was confirmed by the statement of P. I. Pestel'. At the questioning he claimed: "When I stayed in St. Petersburg, prince Sergei Trubetskoi in Moscow received a letter from one of our members, which informed other St. Petersburg members, that their Moscow counterparts were determined to take action and demanded their consent and arrival in Moscow. Prince Trubetskoi asked for a leave and on the same day set off to Moscow with the aim of talking the local members out of this plan and informing them that we have no intention to be engaged in it" ${ }^{54}$. Hence, not only did S. P. Trubetskoi speak against the attempt on the emperor's life, but he strongly objected to the overall plan. The rashness of S.P. Trubetskoi's trip to Moscow in order to make the members of the society change their mind suggests this. However, "when he arrived in Moscow, most of the members had already rejected the regicide idea" 55 .

The analysis of the events and circumstances of the Moscow Conspiracy in the context of the given passage from the correspondence between S. P. Trubetskoi and I. N. Tolstoi enables us to develop a system of the assessment of the key events on the agenda of the secret society in 1817. The news about the unexpected serfdom abolition edict triggered the disappointment in the emperor. The prospect of an immediate solution to the peasant problem convinced the participants that the consequences - an inevitable peasant uprising would not take long to come. Under these circumstances a number of members supported the idea of regicide. However, this plan did not receive the sympathies or approval of S.P. Trubetskoi.

Summing everything we have said before up, it is important to note that the conducted research demonstrates that even at the stage of investigation the government was concerned with the concealment of the peasant causes of the Moscow Conspiracy. This tendency, which can be found in the report of the Committee of Inquiry, defined the perception of this issue by the prerevolutionary historiography. Attempts to revise this opinion were made. However, this process was halted by the formation of the concept of Russian history under Stalin, reflected in the works of M.V.Nechkina. The historian insisted that the movement's main objectives were the deposition of the autocracy and the abolition of serfdom. The idea of interpreting the Moscow Conspiracy as an attempted resistance of the nobility to the authorities' plans to liberate the peasants could become a political paradox. This opinion prevailed both in the Soviet and foreign historiography for a long time. However, in the period of Perestroika S. V. Mironenko in his monograph comes up with the opposite view on this issue arguing that the idea of regicide was related to Alexander I's alleged plans of retiring to Warsaw and sending the Manifest on the Liberation of the Serfs from there. Furthermore, two previously unknown primary sources, discovered by P. V. Il'in and T. V. Andreeva, indicate that the causes of Moscow Conspiracy

${ }^{54}$ Delo P. I. Pestelia // Vosstanie dekabristov. Materialy po istorii vosstaniia dekabristov. Moscow; Leningrad, 1925. Vol. 4. P. 112.

55 Porokh I. V. Deiatel'nost' dekabristov v Moskve (1816-1825 gg.) // Dekabristy v Moskve. Trudy muzeia istorii i rekonstruktsii Moskvy. Moscow, 1963. Vol. 8. P. 23. 
were rooted in the fact that in 1817 the Decembrists strongly opposed to the abolition of serfdom carried out exclusively by the decision of the supreme authorities.

\section{References}

Andreeva T.V., Il'in P.V., Belousov M.S., Ivanova T.A., Kuznetsova S.D., Parshina A.V., Smirnov A.O. Istoricheskaia pamiat' Rossii i dekabristy. 1825-2015. Vestnik of Saint-Peterburg University. History. 2016, issue 2, pp. 168-181. (In Russian)

Andreeva T. V., Il'in P. V. Pis'ma S. P. Trubetskogo I. N. Tolstomu. S. P. Trubetskoi. Zapiski. Pis'ma I. N. Tolstomu 1818-1823 gg. St. Petersburg, Liki Rossii Publ., 2011, pp. 167-182. (In Russian)

Artamonov D.S.Iz istorii "Moskovskogo zagovora" 1817 goda. Osvoboditel'noe dvizhenie v Rossii. Saratov, 2006, vol. 21, pp. 55-67. (In Russian)

Belousov M. S. "Predatel'stvo" S. P. Trubetskogo: pro et contra. Vestnik of Saint-Peterburg University. History. 2014, issue 4, pp. 15-30. (In Russian)

Blackwell W.L.Russian Decembrist views of Poland. The Polish Review. 1958, vol. 3, no. 4, Autumn, pp. 30-54.

Druzhinin N. M. Dekabrist Nikita Murav'ev. N. M. Druzhinin. Revoliutsionnoe dvizhenie v Rossii v XIX veke. Izbrannye trudy. Moscow, Nauka Publ., 1985, pp. 5-304. (In Russian)

Dvornichenko A. Y., Belousov M.S. Dvizhenie dekabristov v tvorchestve Georgiia Vernadskogo. Vestnik of Saint-Peterburg University. History. 2017, vol. 62, issue 2, pp. 358-374. (In Russian)

Il'in P. V. Neizvestnye zapiski S. P. Trubetskogo. S. P. Trubetskoi. Zapiski. Pis'ma I. N. Tolstomu 1818-1823 gg. St. Petersburg, Liki Rossii Publ, 2011, pp. 9-50. (In Russian)

Il'in P.V. Novoe ob istorii dekabristskogo dvizheniia (po stranitsam neizvestnoi rukopisi zapisok S. P. Trubetskogo). Otechestvennaia istoriia. 2003, no. 6, pp. 138-146. (In Russian)

Lavrov N. F. Diktator 14 dekabria. Bunt dekabristov. Leningrad, Buloe Publ., 1926, pp. 129-222. (In Russian)

Mazour A.G. First Russian revolution 1825. The Decembrist movement. Its origins, development and significance. Stanford (California), Stanford University Press, 1937, 338 p.

McCaffray S.P. Confronting Serfdom in the Age of Revolution: Projects for Serf Reform in the Time of Alexander I. The Russian Review, 2005, vol. 64, no. 1, pp. 1-21.

Mironenko S. V. Samoderzhavie i reformy. Politicheskaia bor'ba v Rossii v nachale XIX veka. Moscow, Nauka Publ., 1989, 238 p. (In Russian)

Mironenko S. V. Aleksandr I i dekabristy. Rossiia v pervoi chetverti XIX veka. Vybor puti. Moscow, Kuchkovo pole Publ., 2016, 400 p. (In Russian)

Mironova I. A. Dekabrist Ivan Dmitrievich Iakushkin. Moscow, Prosveshchenie Publ., 1987, 107 p.

Nechkina M. V.Dvizhenie dekabristov. Moscow, Nauka Publ., 1955, vol. 1, 481 p. (In Russian)

Porokh I. V. Deiatel'nost' dekabristov v Moskve (1816-1825 gg.). Dekabristy v Moskve. Trudy muzeia istorii i rekonstruktsii Moskvy. Moscow, 1963, vol. 8, pp. 9-106. (In Russian)

Safonov M. M. "Moskovskii zagovor" 1817 g. i krest'ianskii vopros. Dekabristy v Ukraine. Kiev, 2012, vol. 7, pp. 203-212. (In Russian)

Tumanik E.N.Aleksandr Nikolaevich Murav'ev. Nachalo politicheskoi biografii i osnovanie pervykh dekabristskikh organizatsii. Novosibirsk, Institut istorii, Sibirskoe otdelenie Rossiiskoi akademii nauk Publ., 2006, 372 p. (In Russia)

Vernadskii G. Dva lika dekabristov. Svobodnaia mysl', 1993, no. 15, pp. 81-92. (In Russian)

Walker F. A. Poland in the Decembrists' strategy of revolution. The Polish Review, 1970, vol. 15, no. 2, Spring, pp. 43-54. 